\title{
Entrepreneurial intentions of South African rural university students: A test of the theory of planned behaviour
}

\author{
Justice Malebana \\ Tshwane University of Technology, South Africa \\ malebanamj@tut.ac.za
}

\begin{abstract}
This paper investigates the entrepreneurial intentions of 329 final-year commerce students in a rural university in the Limpopo province. The study is based on the theory of planned behaviour (TPB). The objectives of the study were to test whether the TPB can help explain the entrepreneurial intentions of rural university students; to determine whether rural students will have intentions to start a business and to test the validity of the entrepreneurial intention questionnaire in a South African context. The study was conducted by means of a survey. SPSS was used to analyse the data. The results indicate that entrepreneurial intention of the respondents can be predicted from the attitude towards becoming an entrepreneur, perceived behavioural control and subjective norms. The findings reveal that the TPB is a valuable tool in understanding entrepreneurial intention of rural university students in South Africa. The majority of students intend to start a business in the future and the entrepreneurial intention questionnaire was found to be a valid instrument to measure the entrepreneurial intention of students in a South African context. Recommendations for policy makers, entrepreneurship educators and researchers have been highlighted.
\end{abstract}

Keywords: Entrepreneurial intention, South Africa, Limpopo province, rural university students, Theory of planned behaviour

\section{Introduction}

The South African government views the development of small, medium and micro enterprises (SMMEs) as a mechanism through which it can create jobs, promote economic growth and equity in the country (Department of Trade and Industry, 2004; 2005 \& 2010). Since 1995 a number of measures were put in place to create an enabling environment in which SMMES can be established and grow. However, the total entrepreneurial activity rates of South Africa from 2002 to 2012 had been below the average of all participating countries (Simrie, Herrington, Kew \& Turton, 2012; Turton \& Herrington, 2013). On the other hand the percentage of individuals who have entrepreneurial intentions is currently 14\% (Turton \& Herrington, 2013) which decreased from just close to 18\% in 2011 (Simrie et al., 2012). Entrepreneurial activity in rural areas is also reported to be low when compared to urban areas and is dominated by necessity entrepreneurs (Orford, Herington \& Wood, 2005). These low entrepreneurial activity rates and intention levels call for research regarding what could be the determinants of entrepreneurship in South Africa, with specific reference to the intention to start a business. Entrepreneurship is considered to be an intentionally planned behaviour (Krueger, Reilly \& Carsrud, 2000; Souitaris, Zerbinati \& Al-Laham, 2007; Linan, Nabi \& Krueger, 2013). Hence entrepreneurial intentions precede entrepreneurial action (Shook, Priem \& McGee, 2003; Ajzen, 2005; Kolvereid \& Isaksen, 2006; Krueger, Schulte \& Stamp, 2008; Douglas, 2013). As a result, observing intentions towards the entrepreneurial behaviour can help in predicting this behaviour. Prior research indicates that specific behaviours such as entrepreneurship can be predicted with considerable accuracy from intentions to engage in the behaviours under consideration (Krueger \& Brazeal, 1994; Kickul \& Krueger, 2005; Souitaris et al., 2007). It was also found that greater growth aspiration was significantly associated with higher business growth (Wiklund \& Shepherd, 2003) and entrepreneurial intentions are significantly related to entrepreneurial behaviour (Kolvereid \& Isaksen, 2006; Zhang \& Yang, 2006).

In recent years the popularity of entrepreneurial intention models has increased considerably as a valuable approach for examining the factors that influence individuals' choice for an entrepreneurial career over conventional employment (for example Sesen, 2013; Schwarz, Wdowiak, Almer-Jarz \& Breitnecker, 2009; Kolvereid \& Isaksen, 2006; Segal, Borgia \& Schoenfeld, 2005). Research on entrepreneurial intentions based on entrepreneurial intention models is vital in South Africa since entrepreneurial intentions are the foundation for understanding the new venture creation process (Linan 
et al., 2013; Bird, 1988). Therefore, knowledge of the factors influencing the antecedents of entrepreneurial intentions in South Africa is necessary to guide the development of interventions aimed at promoting entrepreneurship development.

Globally, there is tremendous growth in studies on entrepreneurial intentions (Miralles, Riverola \& Giones, 2012; Iakovleva, Kolvereid \& Stephan, 2011; Liñán \& Chen, 2009; Krueger, 2009). Research on entrepreneurial intentions using entrepreneurial intention models, is scarce in South Africa and developing countries (Nabi \& Liñán, 2011). While the theory of planned behaviour (TPB) has been used to study entrepreneurial intentions of students in two of South Africa's highly urbanised provinces, Gauteng and the Western Cape (Muofhe \& du Toit, 2011; Gird \& Bagraim, 2008), this theory or any other entrepreneurial intention model has not been applied in a rural setting. Therefore, testing the ability of the TPB to predict entrepreneurial intentions of students in a rural setting such as Limpopo province (Statistics South Africa, 2006), could assist in the efforts to promote entrepreneurship development in the province. Increasing the number of people who have the ability and motivation to start businesses in rural areas is vital in ensuring sustainable rural economies. Identifying individuals with the intention to start a business would assist the government in directing support to those who need it in order to contribute to job creation (Douglas, 2013). This paper examines, based on the theory of planned behaviour, whether rural university students in Limpopo have the intention to start their own businesses.

Research objectives: The objectives of this study were:

- To test whether the theory of planned behaviour can help explain the entrepreneurial intention of rural university students.

- To determine whether rural students will have the intentions to start a business.

- To test the validity of the entrepreneurial intention questionnaire in a South African context.

\section{Literature Review}

Entrepreneurial intention models: Various entrepreneurial intention models have been used in the study of entrepreneurial intentions (see Guerrero, Rialp \& Urbano, 2008) but the two dominant formal, theory-driven models of intentions are the theory of planned behaviour (TPB) and Shapero and Sokol's model of entrepreneurial event (SEE) (Nabi \& Holden, 2008; Nabi, Holden \& Walmsley, 2010; Liñán \& Nabi, 2011; Miralles et al., 2012). The empirical tests of these two entrepreneurial intention models revealed that they are compatible (Krueger et al., 2000; Miralles et al., 2012) and valuable in understanding entrepreneurial intentions (Nabi et al., 2010). Nabi et al. (2010) suggest that both the TPB and SEE models have the potential to contribute to individual change since they focus on attitudes and capacity-building. These models are valuable in understanding the determinants of an individual's preference for an entrepreneurial career. Kolvereid, Iakovleva and Kickul (2007) concluded that in an attempt to predict the intention to become self-employed the TPB and the SEE models can be successfully integrated into one model. Researchers have discovered an overlap between the two entrepreneurial intention models on two elements: Shapero and Sokol's construct of perceived desirability is reported as equivalent to Ajzen's determinants of the attitude towards the behaviour (personal attraction) and subjective norms; and perceived feasibility proposed by Shapero and Sokol is similar to Ajzen's perceived behavioural control or to the concept of self-efficacy (Krueger \& Brazeal, 1994; Linan, Urbano \& Guerrero, 2011). Bandura (1986, p. 391) defines self-efficacy as 'people's judgements of their capabilities to organize and execute courses of action required to attain designated types of performances'. Previous research has found a significant relationship between self-efficacy and entrepreneurial intentions (Naktiyok, Karabey \& Gulluce, 2010; Prabhu, McGuire, Drost \& Kwong, 2012; Sanchez, 2013; Akmaliah, Pihie \& Bagheri, 2013; Sesen, 2013). A discussion of the antecedents of entrepreneurial intention in the SEE model and the TPB follows:

Shapero and Sokol's model of entrepreneurial event: The SEE model suggests that entrepreneurial intentions can be predicted from perceived desirability, perceived feasibility and propensity to act (Krueger et al., 2000). In this model an entrepreneurial event is more likely to emerge when individuals feel attracted to the act of starting a business, have perceptions that they are personally capable of starting a business and have an inclination to act on their own decisions. The SEE model proposes that the entrepreneurial event emerges from the interactions between situational, cultural and social variables. Shapero and Sokol (1982) view the entrepreneurial process as an event that is initiated by some sort of displacement event. The appearance (or acquisition) of a perceived facilitator or the removal (or avoidance) of a perceived inhibiting factor are some of the displacement events that could lead to the 
initiation of an entrepreneurial action. Krueger et al. (2008) posit that displacement events could be regarded as triggers to action or barriers to action. Whilst Krueger et al.'s (2000) findings confirmed the predictive validity of the three antecedents of entrepreneurial intention in the SEE model, propensity to act was not significant in Miralles et al.'s (2012) study.

The theory of planned behaviour: The TPB is an extension to the theory of reasoned action that was developed by Ajzen and Fishbein in 1980 (Ajzen, 2005). Ajzen and Cote (2008) regard the TPB as the most influential and popular framework for the prediction of human behaviour. In this theory intentions are reported as good predictors of behaviour when the behaviour is under volitional control (Ajzen \& Fishbein, 2005). The TPB suggests that the most important immediate determinant of action is a person's intention to perform or not to perform that action (Ajzen, 2005). According to the TPB, an individual's intention to start a business can be predicted with high accuracy from the attitude towards the behaviour, subjective norms and perceived behavioural control (Ajzen, 2005, 2012). The attitude towards the behaviour refers to the degree to which a person has a favourable or unfavourable evaluation or appraisal of the behaviour in question. Perceived behavioural control refers to the sense of self-efficacy or ability to perform the behaviour (Ajzen, 2005; Ajzen \& Cote, 2008). Subjective norms refer to the perceived social pressure to perform or not to perform the behaviour. The antecedents of entrepreneurial intention are also influenced by behavioural beliefs, normative beliefs and control beliefs (Ajzen, 2012, 2005; Ajzen \& Cote, 2008). Individuals' actions are guided by their beliefs concerning: the likely outcomes of performing the behaviour and how they evaluate these outcomes; whether significant others expect them to engage in the behaviour and the motivation to comply with these expectations; and whether factors that may facilitate or impede the performance of the behaviour are available and the perceived power of these factors (Ajzen, 2005, 2012).

Since its introduction, the TPB has been empirically tested and validated in numerous studies. These studies include those that focused on the intention to start a business (Krueger et al., 2000; Liñán \& Chen, 2006, 2009; Nishimura \& Tristán, 2011; García-Rodríguez, Gil-Soto, Ruiz-Rosa \& Sene, 2013; Liñán et al., 2013), growth intentions (Douglas, 2013) and the growth decision (Wiklund \& Shepherd, 2003). Liñán and Chen $(2006,2009)$ and Liñán, Rodríguez-Cohard and Rueda-Cantuche (2011) found that subjective norms have an indirect influence on entrepreneurial intention via personal attraction and perceived behavioural control. These findings corroborate those in Krueger et al. (2000); Oruoch (2006); Li (2006); Nishimura and Tristán (2011); Garcia-Rodríguez et al. (2013). On the contrary other studies have reported the full support of the TPB in terms of the three antecedents of entrepreneurial intention (for example, Souitaris et al., 2007; Gird \& Bagraim, 2008; Basu \& Virick, 2008; Engle, Dimitriadi, Gavidia, Schlaegel, Delanoe, Alvarado, He, Buame \& Wolff, 2010; Mueller, 2011; Iakovleva et al., 2011; Angriawan, Conners, Furdek \& Ruth, 2012; Otuya, Kibas, Gichira \& Martin, 2013). The TPB is considered to be a useful framework for the design of interventions and the evaluation of the effectiveness of these interventions in changing beliefs that guide the performance of the behaviour (Ajzen, 2011, 2012). A discussion of the three conceptually independent determinants of intentions in the TPB follows:

Attitude towards the behaviour: Entrepreneurship is defined as a field of study that examines 'how, by whom, and with what effects opportunities to create future goods and services are discovered, evaluated, and exploited' (Shane \& Venkataraman, 2000, p. 218). The exploitation of an entrepreneurial opportunity depends on entrepreneurs' perceptions regarding its expected value. Ajzen (2005) argues that people develop attitudes from the beliefs they hold about the consequences of performing the behaviour. These consequences of the behaviour are referred to as behavioural beliefs, outcome expectancies or costs and benefits (Ajzen \& Fishbein, 2005). More recently, a number of studies have investigated how salient beliefs or perceived outcomes of entrepreneurship affect the intention of starting a business. Personal benefits that can be realised from an entrepreneurial career stimulate entrepreneurial intentions (Volery, Müller, Oser, Naepflin \& del Rey, 2013). Choo and Wong (2006) reported that both intrinsic and extrinsic rewards influence the intention to start a business. Prior research has revealed that the attitude towards entrepreneurship are influenced by salient beliefs with regards to autonomy, authority, economic opportunity and self-realisation (Kolvereid \& Isaksen, 2006), independence, self-actualisation and financial success (Fretschner \& Weber, 2013). Attitudes towards independence, income and ownership have been found to be related to entrepreneurial intentions (Douglas \& Fitzsimmons, 2013). Schwarz et al. (2009) found that the intention to start a business is influenced by students' attitudes towards entrepreneurship, change, money and their perceptions regarding the university support for entrepreneurship while Saeed, Yousafzai, Yani-De-Soriano and Muffatto, (2013) reported the impact of self-realisation, role and recognition on entrepreneurial intentions. Vanevenhoven and Liguori (2013) 
found that entrepreneurial outcome expectations that include financial rewards, independence/autonomy, personal rewards and family security are significantly related to entrepreneurial intentions and self-efficacy. This means that individuals are more likely to have strong intentions of starting a business and belief that they are personally capable of doing so when the act would result in the achievement of these entrepreneurial outcomes. Individuals are also more likely to view the entrepreneurial behaviour favourably when it is approved and positively valued by those close to them and when they strongly believe that they possess the necessary skills to carry out the behaviour (Liñán et al., 2013).

Researchers following the expectancy theory confirm that entrepreneurial outcomes play a significant role in the intention to start and grow a business (Renko, Kroeck \& Bullough, 2012; Edelman, Brush, Manolova \& Greene, 2010). In addition, it has been reported that individuals choose become entrepreneurs because of the greater psychic utility derived from entrepreneurship (Douglas \& Fitzsimmons, 2006, Steffens, Fitzsimmons \& Douglas, 2007) and when the desirability of self-employment is greater than the desirability obtained when working for others (Segal et al., 2005). Individuals can experience the potential benefits or hardships of being an entrepreneur by observing the consequences of the actions of other people who are entrepreneurs. This can have a positive or negative impact on the attitude towards becoming an entrepreneur and also entrepreneurial intentions (Uygun \& Kasimoglu, 2013; Muofhe \& du Toit, 2011; Lapista et al., 2012; Zhang, Duysters \& Cloodt, 2013; Marques, Ferreira, Gomes \& Rodrigues, 2012).

Perceived behavioural control: Perceived behavioural control refers to individuals' assessments of the degree to which they are capable of performing a given behaviour. It is determined by control beliefs concerning the availability of factors that can facilitate or impede performance of the behaviour (Ajzen \& Cote, 2008). These factors may be external or internal and include the availability of resources and opportunities, information, skills and abilities, emotions and compulsions, dependence on others, past experience with the behaviour, second-hand information about the behaviour, observing the experiences of acquaintances and friends and other factors that increase or decrease the perceived difficulty of performing the behaviour in question (Ajzen, 2005, 2011, 2012). Individuals are more likely to feel capable of performing the entrepreneurial behaviour when it is approved and positively valued by others in the society (Liñán et al., 2013). Positive valuations of the entrepreneurial behaviour in both the closer environment and the social environment enhance one's perception of having entrepreneurial skills which in turn influences perceived behavioural control. It was also found that positive valuation of the entrepreneurial behaviour by people in the closer environment increases the knowledge about the entrepreneurial environment (awareness of associations, support systems and access to preferential loans), which enhances perceived behavioural control. Uygun and Kasimoglu (2013) found that experience in a particular sector enhances entrepreneurial self-efficacy which in turn positively influences entrepreneurial intentions. Similarly, Douglas and Fitzsimmons (2013) and Gird and Bagraim (2008) reported a positive relationship between prior self-employment experience and entrepreneurial intentions. It has also been found that having entrepreneurial role models increases self-efficacy and contributes to the development of entrepreneurial intentions (Uygun \& Kasimoglu, 2013; Dohse \& Walter, 2012; Barnir, Watson \& Hutchins, 2011). According to Ramos-Rodríguez, Medina-Garrido, LorenzoGómez \& Ruiz-Navarro (2010), being able to recognise good business opportunities is related to individuals' beliefs that they possess the necessary knowledge and skills to start their own businesses and knowing other people who are entrepreneurs. Drawing from the literature, it seems that institutions that provide entrepreneurial support and their services (whether funding, information, training, mentoring or technical assistance) should be accessible to ensure success in the efforts to encourage individuals to start their own businesses. There is also a need to increase or facilitate opportunities for networking with entrepreneurs, for example, for information sharing relating to the existence of opportunities. These actions can enhance to perceived personal capability of starting a business.

Subjective norms: Subjective norms derive from individuals' beliefs that significant others or groups approve or disapprove of performing a given behaviour; or these social referents themselves engage or do not engage in it (Ajzen, 2005). Significant others may include a person's parents, spouse, close friends, co-workers and even experts in the behaviour of interest. When people believe that most referents with whom they are motivated to comply think they should perform the behaviour, they will perceive social pressure to perform it and vice versa. In line with Ajzen's view, recent research indicates that individuals are more likely to intend to start a business when they have relationships with others who are entrepreneurs themselves (Lapista, Breugst, Heblich \& Patzelt, 2012). The influence of subjective norms 
on the intention to start a business is supported in studies that have been conducted by Souitaris et al. (2007); Gird and Bagraim (2008); Basu and Virick (2008); Engle et al. (2010); Mueller (2011); Iakovleva et al. (2011); Angriawan et al. (2012) and Otuya et al. (2013). From these findings it can be deduced that individuals are more likely to form intentions to start a business when they think that others who are close to them would approve of them in doing so and when they see these people also engaged in the same behaviour. The more individuals perceive that significant others would approve of them when performing a specific behaviour, the likelihood of engaging in the behaviour increases. This also has a positive effect on perceptions regarding the personal capability to execute the behaviour and its attractiveness (Oruoch, 2006; Liñán et al., 2011; Garcia-Rodríguez et al., 2013).

\section{Methodology}

Research design: This study was carried out by means of a survey research. The reason for the choice of a survey was to obtain comparable data from the chosen sample so that similarities and differences can be found. Surveys are relatively efficient ways for collecting large amounts of data (Gravetter \& Forzano, 2006) and they are used in studies that use individuals as units of analysis (Babbie \& Mouton, 2004).

Sample: The population for this study was final year rural university students in the Limpopo Province in South Africa. This group of students was chosen because they were suitable for studying entrepreneurial intentions as they were facing important career decisions on completion of their studies, of which entrepreneurship could be one of them. This is in line with other similar studies such as Krueger et al. (2000); Liñán and Chen (2009) and Liñán et al. (2011). From the abovementioned population a sample of 329 students was obtained using convenience and purposive sampling methods. Purposive sampling involves choosing people for a specific purpose (Leedy \& Ormrod, 2010; Maree, 2010). When using convenience sampling the researcher selects population elements because they are easily and conveniently available (Maree, 2010). While this sample was easily obtained and consisted of people who had to make decisions regarding their future careers upon completion of their studies, it is not a representative sample of all final year students.

\section{Data collection}

Questionnaire design and measures: This study used the entrepreneurial intention questionnaire that was designed and tested by Liñán and Chen $(2006,2009)$. The entrepreneurial intention questionnaire was solely designed for the theory of planned behaviour as it is applied to entrepreneurship (Liñán \& Chen, 2006, 2009; Liñán, 2008; Liñán et al., 2011). Although this questionnaire was initially tested on the Spanish and Taiwanese samples, it has also been validated in both developed and developing countries (for example Guerrero, Lavín \& Álvarez, 2009; Iakovleva et al., 2011; Gerba, 2012; Angriawan et al., 2012; Otuya et al., 2013; Sesen, 2013). The questionnaire as illustrated in Table 1, consisted of questions that were based on the seven-point Likert scale ( $1=$ Strongly disagree and $7=$ Strongly agree) and nominal scales. Likert scale type questions were used for entrepreneurial intention (four items), the attitude towards becoming an entrepreneur (five items), perceived behavioural control (seven items) and subjective norms (three items) whereas nominal scales were used for gender (1=Male and 2=Female) and prior entrepreneurial exposure (whether the respondents currently own a business or have tried to start a business before or were from an entrepreneurial family background ( $1=$ Yes and $2=\mathrm{No})$ ).

This study was mainly concerned with the relationship between the antecedents of entrepreneurial intention (the attitude towards becoming an entrepreneur, perceived behavioural control and subjective norms) and entrepreneurial intention. For this reason the dependent variable was entrepreneurial intention while the independent variables were the attitude towards becoming an entrepreneur, perceived behavioural control and subjective norms. The reliability of the measuring instrument was tested by means of Cronbach's alpha. Garson (2009) states that the cut-off criteria for internal consistency reliability is 0.60 for exploratory research and that alpha of at least 0.70 or higher is required to retain an item in an adequate scale. The Cronbach's alpha scores of the data collection instrument were higher than 0.60 , meaning that it was a reliable tool for use in this research. To ensure reliability of the results the questionnaire was also pre-tested on five students from the targeted population. 
Table 1: Measures of entrepreneurial intention, attitude towards becoming an entrepreneur, perceived behavioural control and subjective norms

\begin{tabular}{|c|c|c|}
\hline Variable & Items & $\begin{array}{l}\text { Cronbach's } \\
\text { alpha }\end{array}$ \\
\hline $\begin{array}{l}\text { Entrepreneurial } \\
\text { intention }\end{array}$ & $\begin{array}{l}\text { I am ready to do anything to be an entrepreneur. } \\
\text { My professional goal is to be an entrepreneur. } \\
\text { I will make every effort to start and run my own business. } \\
\text { I am determined to create a business venture in the future. }\end{array}$ & .750 \\
\hline $\begin{array}{l}\text { Attitude towards } \\
\text { becoming an } \\
\text { entrepreneur }\end{array}$ & $\begin{array}{l}\text { Being an entrepreneur implies more advantages than } \\
\text { disadvantages to me. } \\
\text { A career as an entrepreneur is totally attractive to me. } \\
\text { If I had the opportunity and resources, I would like to start a } \\
\text { business. } \\
\text { Amongst various options, I would rather be an entrepreneur. } \\
\text { Being an entrepreneur would give me great satisfaction. }\end{array}$ & .766 \\
\hline $\begin{array}{l}\text { Perceived } \\
\text { behavioural control }\end{array}$ & $\begin{array}{l}\text { To start a business and keep it working would be easy for me. } \\
\text { I am able to control the creation process of a new business. } \\
\text { I would have complete control over the situation if I start and run a } \\
\text { business. } \\
\text { I am prepared to do anything to be an entrepreneur. } \\
\text { I know all about the necessary practical details needed to start a } \\
\text { business. } \\
\text { If I wanted to, I could easily start and run a business. } \\
\text { If I tried to start a business, I would have a high chance of being } \\
\text { successful. }\end{array}$ & .762 \\
\hline Subjective norms & $\begin{array}{l}\text { My friends would approve of the decision to start a business. } \\
\text { My immediate family would approve of the decision to start a } \\
\text { business. } \\
\text { My colleagues would approve of the decision to start a business. }\end{array}$ & .784 \\
\hline
\end{tabular}

Distribution of questionnaires: Questionnaires were distributed to the students during their lectures. Students were asked to complete the questionnaires in the presence of the researcher and return them immediately after completion. The respondents were informed about the purpose of the research and were asked to participate voluntarily in the study by completing questionnaires. They were also assured of complete anonymity. It took at least 10 minutes to complete the questionnaires.

Data analysis: Data was analysed by means of the SPSS using descriptive statistics and hierarchical multiple regression analysis. Descriptive statistics were used for the frequencies of the sample. The association between the attitude towards becoming an entrepreneur, perceived behavioural control, subjective norms and entrepreneurial intention was tested using hierarchical multiple regression analysis. Before testing the association between the independent variables and the dependent variable, control variables were entered first followed by the second regression that included control variables and independent variables. The last regression consisted of the antecedents of entrepreneurial intention and entrepreneurial intention.

\section{Results and Discussion}

Descriptive statistics of the sample characteristics: This study involved 329 final year rural university students who were registered for various commerce degrees. Of the 329 respondents $58.1 \%$ were female and $41.9 \%$ were male. In terms of age $25.8 \%$ were in the age category between 18 and 21 years, $61.1 \%$ of the respondents were in the age category between 22 and 25 years, $7.6 \%$ were in the age category between 26 and 30 years, $2.7 \%$ were in the age category between 31 and 35 years, while $2.7 \%$ were above 36 years, as shown in Table 2. These statistics mean that about $97 \%$ of the respondents were falling in the youth category. In terms of prior exposure to entrepreneurship for the three questions that were based on a nominal scale, $7 \%$ of the respondents were currently running their own businesses, $32.8 \%$ of the respondents have tried to start a business before while $28.6 \%$ of the respondents were coming from the families with members who were running businesses, as shown in Table 3 . 
Descriptive statistics and correlations among variables are shown in Table 4. The results revealed that being from an entrepreneurial family background and prior start-up experience had a very weak but statistically significant negative correlation with entrepreneurial intention $(\mathrm{p}<.01)$, the attitude towards becoming an entrepreneur $(\mathrm{p}<.01)$, perceived behavioural control $(\mathrm{p}<.01)$ and subjective norms $(\mathrm{p}<$ .01). This is contrary to earlier research that has found that entrepreneurial family background and prior self-employment experience increase the likelihood of becoming an entrepreneur (Douglas \& Fitzsimmons, 2013; Uygun \& Kasimoglu, 2013; Dohse \& Walter, 2012). The results support those of Margues et al. (2012) and Zhang et al. (2013) in the sense that direct experience with the entrepreneurial behaviour or observing relatives who are entrepreneurs may expose one to the outcomes that may negatively impact on the decision to choose an entrepreneurial career. As expected a statistically significant positive correlation $(\mathrm{p}<.01)$ was found between entrepreneurial intention, perceived behavioural control, the attitude towards becoming an entrepreneur and subjective norms. This is in line with previous research (Angriawan et al., 2012; Gerba, 2012; Gird \& Bagraim, 2008). The results suggest that the more positively individuals feel about their capability and the outcomes they are likely to achieve from entrepreneurship and think that significant others would approve of them in starting a business, the higher would be their level of intention to start a business.

Table 2: Gender and age of the respondents

\begin{tabular}{|c|c|c|c|c|c|}
\hline \multicolumn{3}{|c|}{ Gender } & \multicolumn{3}{|c|}{ Age } \\
\hline Gender & $\mathbf{N}$ & Percentage (\%) & Age & $\mathbf{N}$ & Percentage (\%) \\
\hline \multirow[t]{3}{*}{ Male } & 138 & 41.9 & $18-21$ & 85 & 25.8 \\
\hline & & & $22-25$ & 201 & 61.1 \\
\hline & & & $26-30$ & 25 & 7.6 \\
\hline \multirow[t]{2}{*}{ Female } & 191 & 58.1 & $31-35$ & 9 & 2.7 \\
\hline & & & $36+$ & 9 & 2.7 \\
\hline Total & 329 & 100 & Total & 329 & 100 \\
\hline
\end{tabular}

Table 3: Respondents' prior exposure to entrepreneurship

\begin{tabular}{|c|c|c|c|c|c|c|c|c|}
\hline \multicolumn{6}{|c|}{ Prior start-up experience } & \multicolumn{3}{|c|}{ Family members run businesses } \\
\hline $\begin{array}{l}\text { Have tried } \\
\text { to start a } \\
\text { business } \\
\text { before }\end{array}$ & $\mathbf{N}$ & $\begin{array}{l}\text { Percentage } \\
(\%)\end{array}$ & $\begin{array}{l}\text { Currently } \\
\text { runs a } \\
\text { business }\end{array}$ & $\mathbf{N}$ & $\begin{array}{l}\text { Percentage } \\
\text { (\%) }\end{array}$ & $\begin{array}{l}\text { Family } \\
\text { members } \\
\text { run } \\
\text { businesses }\end{array}$ & $\mathbf{N}$ & $\begin{array}{l}\text { Percentage } \\
(\%)\end{array}$ \\
\hline Yes & 108 & 32.8 & Yes & 23 & 7 & Yes & 94 & 28.6 \\
\hline No & 221 & 67.2 & No & 306 & 93 & No & 235 & 71.4 \\
\hline TOTAL & 329 & 100 & TOTAL & 329 & 100 & TOTAL & 329 & 100 \\
\hline
\end{tabular}

Table 4: Descriptive statistics and correlations among variables

\begin{tabular}{|c|c|c|c|c|c|c|c|c|c|c|c|}
\hline & Mean & SD & 1 & 2 & 3 & 4 & 5 & 6 & 7 & 8 & 9 \\
\hline Gender & 1.56 & .515 & 1.000 & & & & & & & & \\
\hline Age & 1.94 & .852 & -.033 & 1.000 & & & & & & & \\
\hline $\begin{array}{l}\text { Currently } \\
\text { business }\end{array}$ & 1.92 & .287 & .042 & $-.105^{*}$ & 1.000 & & & & & & \\
\hline $\begin{array}{l}\text { Entrepreneurial family } \\
\text { background }\end{array}$ & 1.71 & .461 & .083 & .019 & $.133^{* *}$ & 1.000 & & & & & \\
\hline $\begin{array}{ll}\text { Prior } & \text { start-up } \\
\text { experience } & \end{array}$ & 1.65 & .495 & $.133^{* *}$ & $-.134^{* *}$ & $.286^{* *}$ & $.242^{* *}$ & 1.000 & & & & \\
\hline $\begin{array}{lr}\text { Attitude } & \text { towards } \\
\text { becoming } & \text { an } \\
\text { entrepreneur } & \end{array}$ & 2.20 & .952 & -.066 & -.038 & -.055 & $-.178^{* *}$ & $-.173^{* *}$ & 1.000 & & & \\
\hline $\begin{array}{l}\text { Entrepreneurial } \\
\text { intention }\end{array}$ & 2.22 & .960 & -.022 & -.022 & -.061 & $-.174^{* *}$ & $-.173^{* *}$ & $.645^{* *}$ & 1.000 & & \\
\hline $\begin{array}{l}\text { Perceived behavioural } \\
\text { control }\end{array}$ & 2.10 & .977 & -.061 & -.063 & -.017 & $-.154^{* *}$ & $-.201^{* *}$ & $.546^{* *}$ & $.572^{* *}$ & 1.000 & \\
\hline Subjective norms & 2.06 & .949 & -.055 & $-.112 *$ & -.027 & $-.153^{* *}$ & -.102 & $.380^{* *}$ & $.403^{* *}$ & $.473^{* *}$ & 1.000 \\
\hline
\end{tabular}

**. Correlation is significant at the 0.01 level (2-tailed).

*. Correlation is significant at the 0.05 level (2-tailed). 
Entrepreneurial intentions of the respondents: The majority of the respondents as shown in Table 5 had the intention to start their own businesses. This is evident when comparing the percentages of the respondents who 'agreed', 'strongly agreed' and 'totally agreed' against the percentages of those who 'disagreed', 'strongly disagreed' and 'totally disagreed' with the four entrepreneurial intention factors. However, it seems that for more than a third of the respondents becoming an entrepreneur is not their professional goal (a total of $25.6 \%$ disagreed while $11.9 \%$ remained neutral). On the other hand, over $53 \%$ of the respondents totally agreed that they 'will make every effort to start and run their own businesses'. Close to $50 \%$ of the respondents totally agreed that they were 'ready to do anything to be an entrepreneur' and were 'determined to create a business venture in the future'. The results contradict those of Turton and Herrington (2013) in which they reported that 14 percent of individuals in South Africa have entrepreneurial intentions. Since between $60 \%$ and $74 \%$ of the respondents have the intention to start their own businesses, they are a potential pool of entrepreneurs who need various kinds of support to translate their intentions into action by starting new businesses that would create jobs (Douglas, 2013). This is particularly important in order to reduce the $48 \%$ youth unemployment rate (Turton \& Herrington, 2013).

Table 5: Entrepreneurial intentions of the respondents

\begin{tabular}{|c|c|c|c|c|c|c|c|c|c|}
\hline \multirow{2}{*}{$\begin{array}{l}\text { Entrepreneurial } \\
\text { intention }\end{array}$} & \multirow[t]{2}{*}{$\mathbf{N}$} & \multicolumn{8}{|c|}{ Percentage (\%) } \\
\hline & & *TD & *SD & $* \mathbf{D}$ & $* \mathbf{N}$ & ${ }^{*} \mathbf{A}$ & *SA & $* \mathbf{T A}$ & $\begin{array}{l}* \text { TOTAL } \\
\text { AGREED }\end{array}$ \\
\hline $\begin{array}{l}\text { * I am ready to do } \\
\text { anything to be an } \\
\text { entrepreneur }\end{array}$ & 324 & 10.6 & 1.8 & 7.9 & 8.2 & 10.6 & 11.6 & 47.7 & 69.9 \\
\hline $\begin{array}{l}\text { * My professional goal is } \\
\text { to be an entrepreneur }\end{array}$ & 322 & 12.5 & 5.8 & 7.3 & 11.9 & 13.7 & 10.6 & 36.2 & 60.5 \\
\hline $\begin{array}{l}\text { * I will make every effort } \\
\text { to start and run my own } \\
\text { business }\end{array}$ & 322 & 8.8 & 3.0 & 2.4 & 5.8 & 10.9 & 13.7 & 53.2 & 77.8 \\
\hline $\begin{array}{l}\text { * I am determined to } \\
\text { create a business } \\
\text { venture in the future }\end{array}$ & 322 & 6.4 & 2.7 & 6.7 & 8.2 & 10.9 & 13.1 & 49.8 & 73.8 \\
\hline
\end{tabular}

The relationship between the antecedents of entrepreneurial intention and entrepreneurial intention: The regression results for the base model (Model 1) in Table 6 show that control variables only accounted for the least variance $(5 \%)$ in entrepreneurial intention compared to the theoretical antecedents of entrepreneurial intention in model 3. Of the control variables only having tried to start a business before and being from an entrepreneurial family background were statistically significant but negatively related to entrepreneurial intention $(F(5,323)=3.445 ; p<0.01)$. The regression that combined the three antecedents of entrepreneurial intention with control variables in Model 2 accounted for $49.6 \%$ of variance in entrepreneurial intention $(F(8,320)=39.376$; $p<0.01)$, indicating that control variables explained the least variance in entrepreneurial intention.

In line with the theory of planned behaviour, the attitude towards becoming an entrepreneur, perceived behavioural control and subjective norms were statistically significantly associated with entrepreneurial intention $(F(3,325)=105.063 ; p<0.01)$. All the three antecedents of entrepreneurial intention were statistically significant and accounted for $49.2 \%$ of variance in entrepreneurial intention. The attitude towards becoming an entrepreneur explained the most variance in entrepreneurial intention $(45.7 \%)$, followed by perceived behavioural control (27.7\%) and subjective norms explained the least variance in entrepreneurial intention (9.8\%). The results corroborate those of Gird and Bagraim (2008) with regards to the high explanatory power of the attitudes on the intention to start a business, suggesting that attitudes have more influence in South Africa on the decision to embark on an entrepreneurial career compared to the other antecedents of entrepreneurial intention. Similarly, Basu and Virick (2008) found that attitudes have a higher explanatory power on entrepreneurial intention compared to perceived behavioural control and subjective norms. In line with previous research, subjective norms had the lowest impact on entrepreneurial intention (Gird \& Bagraim, 2008; Muller, 2011; Otuya et al., 2013).

In terms of this sample the theory of planned behaviour explained a higher percentage of variance in entrepreneurial intention compared to the findings of Gird and Bagraim (2008) in which it accounted for over $27 \%$. The findings are in full support of the theory of planned behaviour as they indicate that all the 
three antecedents of entrepreneurial intention predict the intention of the respondents to start a business. While the results are in line with earlier research that has fully supported the theory of planned behaviour, as explained previously, more importantly in a South African context, they corroborate those of Gird and Bagraim (2008). The results suggest that the theory of planned behaviour can be a valuable tool for understanding the determinants of entrepreneurial behaviour in South Africa, since intentions precede the performance of the behaviour. Given that South Africa needs more entrepreneurs to create jobs (Orford et al., 2005) available support programs should be targeted at those individuals who have intentions to start their own businesses. Doing so would result in better use of limited resources and contribute to the establishment of new ventures because intentions influence behaviour (Kolvereid \& Isaksen, 2006; Zhang \& Yang 2006; Ajzen, 2012).

Table 6: Hierarchical regression model for the relationship between the antecedents of entrepreneurial intention and entrepreneurial intention

\begin{tabular}{lccc}
\hline & Model 1 & Model 2 & Model 3 \\
\hline Control variables & $\beta$ & $\beta$ & $\beta$ \\
$\quad$ & & \\
$\quad$ Gender & 0.011 & 0.036 & \\
$\quad$ Age & -0.045 & 0.017 & \\
$\quad$ Currently runs a business & -0.006 & -0.019 & \\
$\quad$ Has tried to start a business before & $-0.145^{*}$ & -0.020 & \\
$\quad$ Family members run a business & $-0.140^{*}$ & -0.031 & \\
Independent variable & & & \\
$\quad$ Attitude towards becoming an entrepreneur & & $0.451^{* *}$ & $0.457^{* *}$ \\
$\quad$ Perceived behavioural control & & $0.274^{* *}$ & $0.277^{* *}$ \\
$\quad$ Subjective norms & & $0.098^{*}$ & $0.098^{*}$ \\
& & \\
Multiple $R$ & & 0.704 & 0.702 \\
R Square (R ${ }^{2}$ S & 0.225 & 0.496 & 0.492 \\
$\Delta$ Adjusted $\mathrm{R}^{2}$ & 0.051 & 0.483 & 0.488 \\
$\Delta$ F-Ratio & 0.036 & 39.376 & 105.063 \\
Significance of F & 3.445 & $0.000^{* *}$ & $0.000^{* *}$ \\
\hline
\end{tabular}

${ }^{*} P<.05{ }^{* *} P<.01$

\section{Conclusion}

The purpose of this study was to investigate the entrepreneurial intentions of rural university students in South Africa based on the theory of planned behaviour. The results provide strong evidence that the attitude towards becoming an entrepreneur, perceived behavioural control and subjective norms predict the intention to start a business among rural university students in this study. The findings support previous research regarding the use of the theory of planned behaviour as a valuable model in predicting entrepreneurial intentions (Ajzen, 2005; Souitaris et al., 2007; Basu \& Virick, 2008; Gird \& Bagraim, 2008; Engle et al., 2010; Iakovleva et al., 2011; Mueller, 2011; Angriawan et al., 2012; Otuya et al., 2013). While the findings have supported the theory of planned behaviour, attitudes have a higher explanatory power than other antecedents on the intention of starting a business. This means that efforts to improve entrepreneurial activity rates in South Africa, especially in rural areas, should begin with making entrepreneurship a desirable career option followed by various interventions that can increase the personal capability of starting a business. Entrepreneurship seems to be valued as a viable career option among students in this study. This is largely because they believe that their immediate families, friends and colleagues would approve of their decision to start a business. The findings also support previous research in validating Liñán and Chen's $(2006,2009)$ entrepreneurial intention questionnaire as a reliable tool in measuring the antecedents of entrepreneurial intention and entrepreneurial intention.

The shortcomings of this study lie in the fact that data was collected only once. It is therefore impossible to infer causal relationships and actual behaviour. However, Ajzen and Cote (2008) suggest that the effect of intention on behaviour will be strong when actual control over the behaviour is high rather than low. Therefore, providing entrepreneurial support to individuals who have shown their interest in starting a business would increase perceptions of control over the behaviour. Another limitation is that the study cannot predict the success of entrepreneurs compared to their entrepreneurial intentions. This is because the success of a business depends on coherence between various factors, for example the strategies 
adopted, an entrepreneur's capacity to learn, the state of the environment, and the skills and internal resources which may be implemented differently depending on the various phases of the entrepreneurial process (Fayolle, 2007). In case those who have the intention to start a business decide to establish their own ventures, it would not be possible predict who will achieve this coherence through entrepreneurial intention models.

Recommendations: Entrepreneurship is an intentional activity. An understanding of the antecedents of entrepreneurial intention and the factors impacting on these antecedents is vital in improving the efforts to promote entrepreneurship especially in South Africa where the unemployment rate is high. While the South African government has introduced various SMME support programmes in the past years, the theory of planned behaviour can be a valuable tool in evaluating the impact of such programmes on the intention to start a business and actual start-up of a new venture. As Ajzen (2011) pointed out, behavioural interventions can be evaluated in terms of how they change the antecedents of intention and behaviour. This is specifically more relevant in South Africa where the utilisation of support programmes had been low (DTI, 2010). The design of SMME support programmes should take into consideration the diversity of the needs of the beneficiaries of these programmes and be tailor-made to meet these needs. Firstly, support programmes can be designed to change the mindsets, attitudes and intentions of those who have not thought about entrepreneurship as a viable career. These individuals will benefit from abundant information from various media relating to SMME support, acknowledgement and appreciation of entrepreneurship as a career among the society and celebration of successful entrepreneurship. Secondly, SMME support programmes should be directed to the needs of those who have made up their minds to start their own ventures. In this case support programmes should make it possible for one to start a business. Lastly, SMME support programmes should be targeted to promoting effective management and growth of existing SMMEs. Depending on the focus and goals of the support programmes, all these efforts may contribute to the perceptions that entrepreneurship is desirable and feasible which in turn lead to the intention to act.

For higher education institutions the theory of planned behaviour could be valuable in designing and evaluating the impact of education programmes on the entrepreneurial intentions of students. For example, in entrepreneurship education programmes the theory of planned behaviour can be used to assess the impact of these programmes on changing the antecedents of entrepreneurial intention and ultimately entrepreneurial behaviour. Exposing students to entrepreneurial role models and their businesses and hands-on learning activities would contribute to increased perceptions that an entrepreneurial career is desirable and feasible. The theory of planned behaviour can also be a useful tool for entrepreneurial development. As studies on entrepreneurial intention are still new in South Africa, there is a need for more knowledge regarding the factors influencing the antecedents of entrepreneurial intention with a view to improving entrepreneurial activity. Future research can apply entrepreneurial intention models to examine for example, the impact of entrepreneurship education, entrepreneurial support and culture on entrepreneurial intention and the growth intention.

Acknowledgements: This study was partially funded by the National Research Foundation. The researcher would like to thank Professor Francisco Liñán for the permission to use the Entrepreneurial Intention Questionnaire.

\section{References}

Ajzen, I. (2005). Attitudes, personality and behaviour ( $2^{\text {nd }}$ ed), Berkshire, England: Open University Press.

Ajzen, I. (2011). Behavioural interventions: Design and evaluation guided by the theory of planned behaviour. In M.M. Mark., S.I. Donaldson, \& B.C. Campbell (Eds.) Social psychology for program and policy evaluation (pp. 74-100). New York: Guilford.

Ajzen, I. (2012). The theory of planned behaviour. In Lange, P A. M., Kruglanski, A. W. \& Higgins, E. T. (Eds) Handbook of theories of social psychology, 1, 438-459, Sage, London, UK.

Ajzen, I. \& Cote, N. G. (2008). Attitudes and the prediction of behaviour. In W. D. Crano \& R. Prislin (Eds.) Attitudes and attitude change. New York: Psychology Press (pp. 289-311).

Ajzen, I. \& Fishbein, M. (2005). The influence of attitudes on behaviour. In Albarracin, D., Johnson, B.T. \& Zanna, M.P. The handbook of attitudes. (pp. 173-221): Mahwah, NJ. Erlbaum.

Akmaliah, Z., Pihie, L. \& Bagheri, A. (2013). Self-efficacy and entrepreneurial intention: The mediation effect of self-regulation. Vocations \& Learning, 6, 385-401. 
Angriawan, A., Conners, S. E., Furdek, J. \& Ruth, D. (2012). An empirical examination of entrepreneurial intent in the equine industry. Proceedings of the Academy of Entrepreneurship, 18(1), 1-8.

Bandura, A. (1986). Social foundation of thought and action-A social cognitive theory. Prentice- Hall: Englewood Cliffs, New Jersey.

Barnir, A., Watson, W. E. \& Hutchins, H. M. (2011). Mediation and moderated mediation in the relationship among role models, self-efficacy, entrepreneurial career intention, and gender. Journal of Applied Social Psychology, 42(2), 270-297.

Basu, A. \& Virick, M. (2008). Assessing entrepreneurial intentions amongst students: A comparative study. Available online at: http://nciia.org/conf08/assets/pub/basu2.pdf (accessed 04 November 2013).

Bird, B. (1988). Implementing entrepreneurial ideas: The case for intention. The Academy of Management Review, 13(3), 442-453.

Choo, S. \& Wong, M. (2006). Entrepreneurial intention: Triggers and barriers to new venture creations in Singapore. Singapore Management Review, 28(2), 47-64.

Department of Trade and Industry. (2004). Review of ten years of small business support in South Africa 1994-2004. Available online at: http://www.tips.org.za/files/10_years_of_Small_ Business_support_in_South_Africa.pdf (accessed 29 May 2009).

Department of Trade and Industry. (2005). Integrated strategy on the promotion of entrepreneurship and small enterprises. Available online at: http://www.dti.gov.za/sme_development/docs/strategy.pdf (accessed 11 November 2013).

Department of Trade and Industry. (2010). National directory of small business support programmes. Available online at: http://www.dti.gov.za (accessed 02 April 2013).

Dohse, D. \& Walter, S. G. (2012). Knowledge context and entrepreneurial intentions among students. Small Business Economics, 39, 877-895.

Douglas, E. J. (2013). Reconstructing entrepreneurial intentions to identify predisposition for growth. Journal of Business Venturing, 28, 633-651.

Douglas, E. \& Fitzsimmons, J. (2006). Entrepreneurial capital and entrepreneurial intentions: A crosscultural comparison. Available online at: http://www.babson.edu.entrep/fer/2005FER/chapter_v/summary_v2.html (accessed 09 August 2007).

Douglas, E. J. \& Fitzsimmons, J. R. (2013). Intrapreneurial intentions versus entrepreneurial intentions: distinct constructs with different antecedents. Small Business Economics, 41, 115-132.

Engle, R. L., Dimitriadi, N., Gavidia, J. E., Schlaegel, C., Delanoe, S., Alvarado, I., He, X., Buame, S. \& Wolff, B. (2010). Entrepreneurial intent: A twelve-country evaluation of Ajzen's model of planned behaviour. International Journal of Entrepreneurial Behaviour \& Research, 16(1), 35-57.

Fayolle, A. (2007). Entrepreneurship and new value creation-The dynamic of the entrepreneurial process, ( $1^{\text {st }}$ ed), United Kingdom: Cambridge University Press.

Fretschner, M. \& Weber, S. (2013). Measuring and understanding the effects of entrepreneurial awareness education. Journal of Small Business Management, 51(3), 410-428.

García-Rodríguez, F. J., Gil-Soto, E., Ruiz-Rosa, I. \& Sene, P. M. (2013). Entrepreneurial intentions in diverse development contexts: A cross-cultural comparison between Senegal and Spain. International Entrepreneurship \& Management Journal, DOI 10.1007/s11365-013-0291-2.

Garson, D. (2009). Reliability analysis. Available online at: http://faculty.chass.ncsu.edu/garson/PA765/reliab.htm (accessed 20 March 2009).

Gerba, D. T. (2012). Impact of entrepreneurship education on entrepreneurial intentions of business and engineering students in Ethiopia. African Journal of Economic \& Management Studies, 3(2), 258277.

Gird, A. \& Bagraim, J. J. (2008). The theory of planned behaviour as predictor of entrepreneurial intent amongst final-year university students. South African Journal of Psychology, 38(4), 711-724.

Guerrero, M., Lavín, J. \& Álvarez, M. (2009). The role of education on start-up intentions: A structural equation model of Mexican university students. Paper presented at the $35^{\text {th }}$ annual conference proceedings of the Association for Small Business and Entrepreneurship.

Guerrero, M., Rialp, J. \& Urbano, D. (2008). The impact of desirability and feasibility on entrepreneurial intentions: A structural equation model. International Entrepreneurship \& Management Journal, 4, 35-50.

Iakovleva, T., Kolvereid, L. \& Stephan, U. (2011). Entrepreneurial intentions in developing and developed countries. Education \& Training, 53(5), 353-370. 
Kickul, J. \& Krueger, N. (2005). A cognitive processing model of entrepreneurial self-efficacy and intentionality. Available online at: http://www.babson.edu/entrep/fer/FER_2004/webcontent/section\%XXII/P3/XXII-P3... (accessed 10 November 2006).

Kolvereid, L., Iakovleva, T. \& Kickul, J. (2007). An integrated model of entrepreneurial intentions. Available online http://www.babson.edu/entrep/fer/2006FER/chapter_viii/summary_viii_2.html (accessed 09 August 2007). Full article received from the authors.

Kolvereid, L. \& Isaksen, E. (2006). New business start-up and subsequent entry into self-employment. Journal of Business Venturing, 21, 866-885.

Krueger, N. (2009). The micro foundations of entrepreneurial learning and education: The experiential essence of entrepreneurial cognition and implications for entrepreneurial pedagogies. Paper presented at USASBE 2009 conference proceedings, January 8-11, Anaheim, CA.

Krueger, N. F. \& Brazeal, D. V. (1994). Entrepreneurial potential and potential entrepreneurs. Entrepreneurship Theory \& Practice, 4, 91-104.

Krueger, N. F., Reilly, M. D. \& Carsrud, A. L. (2000). Competing models of entrepreneurial intentions. Journal of Business Venturing, 15, 411-432.

Krueger, N., Schulte, W. \& Stamp, J. (2008). Beyond intent: Antecedents of resilience \& precipitating events for social entrepreneurial intentions and action. Available online at: http://sbaer.uca.edu/research/usasbe/2008/pdf/PaperID242.pdf (accessed 05 February 2009).

Lapista, S., Breugst, N., Heblich, S. \& Patzelt, H. (2012). Intergenerational transmission of entrepreneurial intentions. Journal of Business Venturing, 27, 414-435.

Li, W. (2006). Entrepreneurial intention among international students: Testing a model of entrepreneurial intention. Available online at: http://www.sbaer.uca.edu/research/usasbe/2006/pdffiles/toc_cases.pdf (accessed 13 March 2006).

Liñán, F. (2008). Skill and value perceptions: how do they affect entrepreneurial intentions? International Entrepreneurship \& Management Journal, 4, 257-272.

Liñán, F. \& Chen, Y. (2006). Testing the entrepreneurial intention model on a two-country sample. Available online at: http://www.recercat.net/bitstream/2072/2213/1/UABDT06-7.pdf (accessed 28 August 2007).

Liñán, F. \& Chen, Y. (2009). Development and cross-cultural application of a specific instrument to measure entrepreneurial intentions. Entrepreneurship Theory \& Practice, 5, 593-617.

Liñán, F., Nabi, G. \& Krueger, N. (2013). British and Spanish entrepreneurial intentions: A comparative study. Revista De Economia Mundial, 33, 73-103.

Liñán, F., Rodriguez-Cohard, J. C. \& Rueda-Cantuche, J. M. (2011). Factors affecting entrepreneurial intention levels. A role for education. International Entrepreneurship \& Management Journal, 7, 195-218.

Liñán, F., Urbano, D. \& Guerrero, M. (2011). Regional variations in entrepreneurial cognitions: Start-up intentions of university students in Spain. Entrepreneurship \& Regional Development, 23(3), 187215.

Marques, C. S., Ferreira, J. J., Gomes, D. N. \& Rodriques, R. G. (2012). Entrepreneurship education: How psychological, demographic and behavioural factors predict the entrepreneurial intention. Education \& Training, 54 (8/9), 657-672.

Miralles, F., Riverola, C. \& Giones, F. (2012). Analysing nascent entrepreneurs' behaviour through intention-Based models. Available online at: http://blogs.salleurl.edu/itmanagement/files/2012/10/MirallesRiverolaGiones_ECIE_Analysing NascentEntrepreneursBehaviour_v2-03.pdf (accessed 07 November 2013).

Mueller, S. (2011). Increasing entrepreneurial intention: effective entrepreneurship course characteristics. International Journal of Entrepreneurship \& Small Business, 13(1), 55-74.

Muofhe, N. J. \& du Toit, W. (2011). Entrepreneurial education's and role models' influence on career choice. South African Journal of Human Resource Management, 9(1), Art. \#345, 15 pages. http://dx.doi.org/10.4102/sajhrm.v9i1.345.

Nabi, G., Holden, R. \& Walmsley, A. (2010). Entrepreneurial intentions among students: towards a refocused research agenda. Journal of Small Business \& Enterprise Development, 17(4), 537-551.

Nabi, G. \& Holden, R. (2008). Graduate entrepreneurship: intentions, education and training. Education \& Training, 50(7), 545-551.

Nabi, G. \& Liñán, F. (2011). Graduate entrepreneurship in the developing world: intentions, education and development. Education \& Training, 53(5), 325-334. 
Naktiyok, A., Karabey, C. N. \& Gulluce, A. C. (2010). Entrepreneurial self-efficacy and entrepreneurial intention: the Turkish case. International Entrepreneurship \& Management Journal, 6, 419-435.

Nishimura, J. S. \& Tristán, O. M. (2011). Using the theory of planned behaviour to predict nascent entrepreneurship. Academia, Revista Latinoamericana de Administración, 46, 55-71.

Orford, J., Herrington, M. \& Wood, E. (2005). Global entrepreneurship monitor-2004 South African executive report. Available online at: http://www.gemconsortium.org/docs/600/gem-southafrica-2004-report (accessed 02 April 2013).

Oruoch, D. M. (2006). Factors that facilitate intention to venture creation among nascent entrepreneursKenyan case. Available online at: http://www.weatherhead.case.edu/edm/archive/Files/year3/oruoch\%20_\%20TYRP\%20FINAL _DRAFT.pdf (accessed 03 March 2008).

Otuya, R., Kibas, P., Gichira, R. \& Martin, W. (2013). Entrepreneurship education: Influencing students' entrepreneurial intentions. International Journal of Innovative Research \& Studies, 2(4), 132-148.

Prabhu, V. P., McGuire, S. J., Drost, E. A. \& Kwong, K. K. (2012). Proactive personality and entrepreneurial intent-Is entrepreneurial self-efficacy a mediator or moderator? International Journal of Entrepreneurial Behaviour \& Research, 18(5), 559-586.

Ramos-Rodríguez, A., Medina-Garrido, J., Lorenzo-Gómez, J. \& Ruiz-Navarro, J. (2010). What you know or who you know? The role of intellectual capital and social capital in opportunity recognition. International Small Business Journal, 28(6), 566-582.

Renko, M., Kroeck, K. G. \& Bullough, A. (2012). Expectancy theory and nascent entrepreneurship. Small Business Economics, 39, 667-684.

Saeed, S., Yousafzai, S. Y., Yani-De-Soriano, M. \& Muffatto, M. (2013). The role of perceived university support in the formation of students' entrepreneurial intention. Journal of Small Business Management, doi: 10.1111/jsbm.12090.

Sánchez, J. C. (2013). The impact of an entrepreneurship education program on entrepreneurial competencies and intention. Journal of Small Business Management, 51(3), 447-465.

Schwarz, E. J., Wdowiak, M. A., Almer-Jarz, D. A. \& Breitenecker, R. J. (2009). The effects of attitudes and perceived environment conditions on students' entrepreneurial intent: An Austrian perspective. Education \& Training, 51(4), 272-291.

Sesen, H. (2013). Personality or environment? A comprehensive study on the entrepreneurial intentions of university students. Education \& Training, 55(7), 624-640.

Segal, G., Borgia, D. \& Schoenfeld, J. (2005). The motivation to become an entrepreneur. International Journal of Entrepreneurial Behaviour \& Research, 11(1), 42-57.

Shane, S. \& Venkataraman, S. (2000). The promise of entrepreneurship as a field of research, Academy of Management Review, 25(1), 217-226.

Shapero, K. G. \& Sokol, L. (1982). The social dimensions of entrepreneurship. In Kent, C., Sexton, D. and Vesper, K. (eds.) The encyclopedia of entrepreneurship. Englewood Cliffs: Prentice-Hall, 72-90.

Shook, C. L., Priem, R. L. \& McGee, J. E. (2003). Venture creation and the enterprising individual: A review and synthesis. Journal of Management, 29(3), 370-399.

Simrie, M., Herrington, M., Kew, J. \& Turton, N. (2012). GEM South Africa 2011 report, Available online at: http://www.gemconsortium.org/docs/2313/gem-south-africa-2011-report (accessed 26 October 2012).

Souitaris, V., Zerbinati, S. \& Al-Laham, A. (2007). Do entrepreneurship programmes raise entrepreneurial intention of science and engineering students? The effect of learning, inspiration and resources. Journal of Business Venturing, 22, 566-591.

Statistics South Africa. (2006). Migration and urbanisation in South Africa. Pretoria. Available online at: www.statssa.gov.za (accessed 05 October 2007).

Steffens, P., Fitzsimmons, J. R. \& Douglas, E. J. (2007). A choice modelling approach to predict entrepreneurial intentions from attitudes and perceived abilities. Available online at: http://www.babson.edu/entrep/Fer/2006FER/chapter_viii/paper_viii_3.html (accessed 07 September 2007).

Turton, N. \& Herrington, M. (2013). Global entrepreneurship monitor 2012-South Africa. Available online at: http://www.gemconsortium.org/docs/2801/gem-south-africa-2012-report (accessed 20 May 2013).

Uygun, R. \& Kasimoglu, M. (2013). The emergence of entrepreneurial intentions in indigenous entrepreneurs: The role of personal background on the antecedents of intentions. International Journal of Business Management, 8(5), 24-40.

Vanevenhoven, J. \& Liguori, E. (2013). The impact of entrepreneurship education: Introducing the entrepreneurship education project. Journal of small business management, 51(30), 315-328. 
Volery, T., Müller, S., Oser, F., Naepflin, C. \& del Rey, N. (2013). The impact of entrepreneurship education on human capital at upper-secondary level. Journal of Small Business Management, 51(3), 429446.

Wickham, P. A. (2006). Strategic entrepreneurship, (4th ed). England: Pearson Education.

Wiklund, J. \& Shepherd, D. (2003). Aspiring for, and achieving growth: The moderating role of resources and opportunities. Journal of Management Studies, 40(8), 1919-1941.

Zhang, Y., Duysters, G. \& Cloodt, M. (2013). The role of entrepreneurship education as a predictor of university students' entrepreneurial intention. International Entrepreneurship \& Management Journal, DOI 10. 1007/s11365-012-0246-z.

Zhang, Y. \& Yang, J. (2006). New venture creation: Evidence from an investigation into Chinese entrepreneurship. Journal of Small Business \& Enterprise Development, 13(2), 161-173. 